Revista Latinoamericana de la Papa 19 (2): 76-81

http://www.papaslatinas.org/revista.html

ISSN: $1853-4961$

\title{
World History of the Potato
}

\author{
J. W. Bentley ${ }^{1 * *}$
}

Received: 13/08/2015

Accepted: 11/09/2015

Accessible on line: December 2015

\section{Summary}

Potatoes were first domesticated, along with the sweet potato and other Andean crops, perhaps as early as 7000 BP, although native South Americans had been eating wild potatoes for at least four thousand years before that. The cause of domestication is imperfectly understood, but it was probably some sort of environmental adaptation and not simply the result of invention. After the Spanish conquest, it took centuries (from the early 1500s to the 1800s) for Europeans to fully adopt the potato. The Irish Potato Famine (1845 to 1859) was caused by careless government, as much as by late blight. The French fry was invented in Belgium or Holland before 1680, and the frozen, pre-fabricated, fry was created in the late 1940s.

Additional key words: history, domestication, Andes, archaeology, Irish potato famine

\section{Historia Mundial de la Papa}

\section{Resumen}

La papa fue domesticada junta con el camote y otros cultivos andinos, posiblemente hasta hace 7000 años, aunque los nativos de Sudamérica ya habían estado comiendo las papas silvestres durante cuatro mil años o más. No se entiende perfectamente la causa de la domesticación, pero fue probablemente algún tipo de adaptación ambiental y no el resultado de la llana invención. Después de la conquista de las Américas, tardó varios siglos (desde principios de los 1500 hasta los 1800s) para que los europeos plenamente adoptaran la papa. La Hambruna Irlandesa de la Papa (1845 a 1859) tuvo su causa en el descuido gubernamental, tanto como en el tizón tardío. La papa frita fue inventada en Bélgica u Holanda antes del 1680, mientras la papa congelada y prefabricada para freír se creó en la última parte de la década de los 1940.

Palabras claves adicionales: historia, domesticación, andes, arqueología, hambruna irlandesa de la papa.

\footnotetext{
* Contact author. E-mail: Jeff@agroinsight.com

${ }^{1}$ Agricultural Anthropologist. Agro-Insight, Cochabamba, Bolivia.
} 


\section{Domestication of the potato}

\section{Introduction}

The study of domestication is an interdisciplinary no-person's land, contested by archaeologists, cultural anthropologists and botanists, among others. Each has a different angle on what domestication was and means.

\section{Cultural anthropology}

Cultural anthropologists explain that domestication was not an invention. This is counter-intuitive for agronomists and agricultural scientists, who are used to seeing all technical change as the result of research.

Domestication began with the start of agriculture, and in many ways was the start of agriculture, before which all humans were hunters and gatherers, who used many species of plants over vast areas of land.

Hunter-gatherers have a very low population density, an abundant and diverse diet, and low labor costs. They do not have to plant or do other time-consuming work associated with agriculture. Hunter-gatherers only harvest.

The people who domesticated the first crops are long gone. We cannot interview them, which is the anthropologist's favorite method. But we can talk, or at least until recently we could talk to living huntergatherers.

In the 1970s, Richard Lee (Lee \& DeVore 1976) did a classic, quantitative study of one of the few groups of hunter-gatherers still existing, the San people of the Kalahari Desert in southern Africa. Lee calculated that the San worked 19 hours a week. And this was in the middle of a drought that was punishing the region. Bantu-speaking peasants had taken refuge with the San because their crops had been lost. But the San had plenty of food.

Half of their calories came from a nut, the mongongo (Schinziophyton rautanenii). When Lee asked them why they did not sow crops, the San answered. "Why should we plant crops, when there are so many mongongos?"

Domestication was not an invention. No one shouted eureka. Ancient peoples knew a great deal about plants. They spent their whole lives observing plants and making food, clothing and tools from their fruits, fibers, roots and resins. It is absurd to think that ancient peoples, like those living in the centers of domestication, would not have realized all along how plants reproduce.

Another anthropologist, William Balée, did a study among the Ka'apor of Brazil. He describes how a group of women hunt a paca or jochi (Cuniculus paca), digging it out of its burrow. To hunt, people make use of their knowledge of the animals they eat. Knowing that the jochi eats Brazil nuts, the Ka'apor hunt jochis where the Brazil nuts have fallen to the forest floor.

The Ka'apor fish with plant poisons and they know which plants they can use to poison fish in different kinds of streams. People gather fruit during 20 minutes a day, generally while they do other things. They collect 179 wild, edible plants. In other words, the Ka'apor have a great botanical knowledge, and it is only reasonable to assume that people living 10,000 years ago also knew much about plants.

In ancient times, before agriculture, no one wanted to plant crops, because it was too much work. But at some time they decided to make the effort, in order to harvest a little more per unit of land. 


\section{Archaeology}

Native Americans were settling the coast of Chile 11,000 BC. Wild potatoes appear in the archaeological sites they left behind.

Domestication of the potato must have involved a large area, over several centuries, perhaps in Bolivia as well. The first domesticates took a couple of thousand years to show genetic change. It was a slow adaptation.

The first clear evidence is from Cañón del Chilca, in a cave called Tres Ventanas, in the department of Lima, near the coast at 4900 $\mathrm{BC}$, at an elevation of 2800 meters. The potato was domesticated along with the sweet potato. Caves in Ancash (north of Lima) held remains of beans, chile, oca, and olluco at about 8,000 BC.

In those times, the Andes were a very different place from what they are now. There were glaciers above 3000 meters. A large lake covered much of what is today the Altiplano. Sea level was at least 10 meters below its current level. The coast was $10 \mathrm{~km}$ further out than it is today. All of the old archaeological sites of the coast from that period of time are now under water. Mastodons, horses and camelids were common in South America.

Domestication could have started in the camps of those first Americans. They were not nomads, wandering about. In fact, hunter-gatherers are rarely if ever nomads. They have a certain annual round, based on a calendar of where food and water appear at different months.

If ancient hunter-gatherers brought wild plants to camp to eat them, the seeds could sprout as volunteer plants. Donald Ugent and Linda Peterson (1988) believe that these plants could have hybridized, which is often part of domestication Then people would keep eating the hybrids, which would have gradually spread along the networks of paths to other ancient camps. At first they probably started by planting potatoes, then following their circuit, and then returning to harvest, without having to do other tasks such as weeding.

Shortly after the end of the glaciers, the climate became dryer, which might have persuaded people to take on the necessary work of planting and caring for their plants.

In the Calma Valley, $360 \mathrm{~km}$ north of Lima, there are four archaeological sites that yield potatoes, such as Pampa de Llamas at 1800 to $1500 \mathrm{BC}$, along with avocado, beans, lúcuma (a fruit), manioc, Chile and others. In all of these coastal sites, plant remains are accompanied by the remains of seafood, a steady source of protein that combined well with coastal crops to form an economic base for settled life.

The archaeologist Clark Erickson (2000) writes that it is possible that the Titicaca Basin was too dry for agriculture until 3500 BP. Yet the first people in the area arrived about 8,000 BP.

The area around Lake Titicaca could have been a center for the origin and domestication of bitter potatoes, according to Francisco Morales (2007). To conserve and transport potatoes, they had to be made into "chuño" by freeze-drying them in the frigid winter nights of the high Andes. Chuño is made from bitter potatoes, and it can be traded for products on other ecological "floors".

Erickson explains that by about $1500 \mathrm{BC}$ the remains of potato, quinoa, and cañahua appear in archaeological sites in the Titicaca Basin, before the agro-pastoral economy had become well established. By 1000 BC, 
people around Titicaca were starting to plant in raised beds or waru warus.

In the centuries before the Spanish conquest, Andean empires like the Wari and Tiwanaku dominated the coast. They produced 30,000 tons of potatoes around the lake (FernándezArmesto 2000).

\section{Genetics}

Based only on genetic evidence, David Spooner and colleagues (2005) affirm that the potato was domesticated 7000 years ago in Peru, Bolivia and northern Argentina. According to genetic evidence, the potato appears a little earlier, and over a larger area than what archaeology tells us, but in reality, it is consistent with archaeological evidence.

Archaeological evidence is difficult to gather. It is possible to find more evidence of domestication in Peru, because they have looked more in Peru, and because the Peruvian coast is very dry, and is ideal for preserving plant remains. Wild potatoes are found in Bolivia and it is possible that a future archaeologist could find ancient potatoes in Bolivia.

\section{Discussion}

Domestication has an air of mystery. During 30,000 years or more, human beings were painting caves, carving ivory, making artefacts like harpoons and doing other things that suggest that they were modern in every way, with the same feelings that we have now, yet in all that time they did not domesticate plants.

Then during a few thousand years, they started to domesticate maize and cucurbits in Mexico, bananas in New Guinea, rice in China, wheat and barley in the Fertile Crescent, and other crops in other places. No one understands exactly why. Climate change? Population growth? Both processes at once?
It is also remarkable that people never domesticated just one crop. In the centers of origin, ancient start-up farmers domesticated several crops at a time. This is why the Andes are not only the birthplace of the potato, but also of sweet potato, oca, olluco, quinoa, cañahua, and other crops.

Domestication may depend on a mix of: 1) having a certain knowledge, and curiosity about plants and the urge to experiment, 2) the need to increase production (perhaps spurred on by climate change, especially by a harsher, dryer climate), and 3) having wild species that lend themselves to domestication.

Once domestication started, there was no turning back. Domestication allowed for a denser human population, which could no longer live from gathering wild plants.

\section{Potatoes leave the Andes}

\section{Europe}

From the very first days of the Spanish conquest, the conquistadores were obliged to eat native foods, and to provision their ships with American crops.

By the 1500s sailors from Galicia were planting potatoes in their home gardens. The potato is documented in Spain in 1533 and in France in 1540. Outside of Spain, the potato was avoided, because of its resemblance to the deadly nightshade.

Europe had several crops which yielded well, and which were well adapted to the labor demands of the agricultural calendar.

The potato expanded slowly in Europe. By the mid- $18^{\text {th }}$ century, the potato was grown and eaten in northern Italy, and in Spain, Germany and Poland.

The potato had one advantage. Since it was below ground, it was difficult for an enemy army to destroy. It could not be burned in the field. Potatoes were bulkier than wheat, and harder for foraging soldiers to carry off. 
The potato became really important in Europe during the Little Ice Age, more or less between 1650 and 1850, when the temperature dropped by an average of one degree centigrade. The potato produced better than many other crops, and it is believed that it helped many people to survive the famines.

Except in France, where people resisted eating it. The potato was produced in France, but as animal fodder. Antoine Parmentier introduced the potato to French cuisine in 1771. He planted a potato field near Paris and set some soldiers to guard it, but just a little. He said that it was a variety reserved for royalty. And the peasants snuck in and stole seed potatoes to cultivate.

The potato that was first introduced to Europe was the andigena subspecies. But by the $19^{\text {th }}$ century, it had been replaced by the tuberosum subspecies, from the south of Chile, which was already adapted to long days, and this sub-species increased the production of potatoes in Europe, and their enhanced their acceptance.

\section{Famine in Ireland}

If the potato helped to save people from famine during the Little Ice Age, the tuber has been implicated in the most famous famine of all. The potato arrived in Ireland in the early 1800s and expanded rapidly, as a basic food commodity. The Irish were in crisis, because it was against British law for Catholics to own land. The peasants owed rent to the landowner, who was usually absentee. The rent was paid in grains, and the potato was to eat.

Over its four or six years, the famine was caused by Phytophthora (blight). Many plant pathology books start with this scene. But Phytophthora was not the lone cause of the famine, which started in 1845. During the first two years of the famine, the potato blight was serious. The third year was disease-free, but little was harvested because almost all of the seed had been lost. The blight came back on the fourth year, especially in the west of the island. The famine was not really over until 1850 .

A million people died, out of a population of 8 million. Another million emigrated immediately and they kept leaving for seventy years, until Ireland was left with half of its population (Woodham-Smith 1962).

The colonial government managed the famine badly, in part because the government trusted the market to solve the problem. But the market did not take food to the poor people, because they had no money.

The moral of the story is that the famine was not caused by Phytophthora or by monocropping, but by religious intolerance and by a government that taxed people but then did little to feed them during the crisis. Because the land tax was paid in grain, Ireland was a food exporter during the famine. Forgiving the rent payment would have been enough to save almost all the lives that were lost.

\section{Fried potatoes}

By some accounts, the fried potato was invented by a Belgian baker. No one knows the truth, but the French fry was invented before 1680, in Belgium or Holland. For many years, the fried potato was cut with a knife, and fried fresh.

In the late 1940s, an American named Jack Simplot invented a thin, frozen fried potato. Ray Kroc, the owner of McDonalds, liked them and bought a contract with Simplot. The French fry ignited the expansion of fast food.

It was a food revolution in the USA. Fast food (especially soft drinks) have 
contributed to the obesity epidemic now rampant in the USA.

\section{Conclusions}

The domestication of the potato was almost certainly not an invention, but was probably part of a long adaptation to climate change in South America. The Europeans only slowly adopted the potato, only accepting its advantages over centuries. So we should be patient with farmers and consumers today, who may take a while to make changes at their own pace. The Irish potato famine was not caused by a disease, but by bad government, which still exists here and there on the Earth today. Not all innovations are healthy, as we see in the case of the frozen, machine-made fast food French fry.

\section{Conflicts of interest}

This publication has no conflicts of interest.

\section{References}

Erickson, C.L. 2000 "The Lake Titicaca Basin: A Precolumbian Built Landscape", Page 311-356 in David Lentz (ed.) Imperfect Balance: Landscape Transformations in the Precolumbian Americas. New York: Colombia University.
Fernández-Armesto, F. 2000. Civilizations. London: Macmillan Publishers. 636 pp.

Lee, R.B.; DeVore, I. 1976 Kalahari Hunter-Gatherers: Studies of the !Kung San and Their Neighbors. Cambridge: Harvard University Press.

Morales-Garzón, F.J. 2007. Sociedades Precolombinas Asociadas a la Domesticación y Cultivo de la Papa (Solanum tuberosum) en Sudamérica. Revista Latinoamericana de la Papa 14 (1): 1-9.

Spooner, D.M.; McLean, K.; Ramsay, G.; R Waugh, R.; Bryan G.J. 2005 "A Single Domestication for Potato Based on Multilocus Amplified Fragment Length Polymorphism Genotyping." Proceedings of the National Academy of Sciences 102 (41):14694-14699.

Ugent, D.; Linda, Peterson, W. 1988 "Archaeological Remains of Potato and Sweet Potato in Peru. CIP Circular 16(3): 110.

Woodham-Smith, C. 1962 The Great Hunger, Ireland 1845-1849. London: H. Hamilton. 